\title{
PENGARUH SENAM PROGRAM PENGOLAHAN PENYAKIT KRONIS (PROLANIS) TERHADAP PENURUNAN TEKANAN DARAH PADA LANSIA HIPERTENSI
}

\author{
Helfrida Situmorang ${ }^{1}$ Nur Dewi Yana ${ }^{2}$ \\ ${ }^{1}$ Dosen STIKes Flora, Medan, Indonesia \\ ${ }^{2}$ Mahasiswa STIKes Flora, Medan, Indonesia \\ Email : situmoranghelfrida@gmail.com, nurdewiyana@gmail.com
}

\begin{abstract}
Abstrak
PROLANIS merupakan suatu pendekatan proaktif dan sistem pelayanan kesehatan yang melibatkan peserta, Fasilitas Kesehatan, dan BPJS Kesehatan dalam rangka pemeliharaan kesehatan bagi peserta BPJS Kesehatan yang menderita penyakit kronis yang dilaksanakan secara terintegratif dengan biaya pelayanan kesehatan yang efektif dan efisien untuk mencapai kualitas hidup yang optimal.Tekanan darah tidak konstan namun dipengaruhi oleh banyak faktor secara kontinu sepanjang hari. Tekanan darah dapat berubah dari satu denyut jantung ke denyut lainnya meskipun saat dalam kondisi yang paling baik. Penyakit darah tinggi atau yang lebih dikenal dengan sebutan hipertensi adalah suatu keadaan dimana tekanan darah seseorang berada diatas batas normal atau optimal yaitu untuk sistolik 120 $\mathrm{mmHg}$ dan untuk diastolic $80 \mathrm{mmHg}$. Penderita yang tidak mengetahui dirinya mengidap hipertensi sebelum memeriksakan tekanan darahnya dikategorikan sebagai the silent disease. Tujuan dari penelitian ini adalah PROLANIS merupakan suatu pendekatan proaktif dan sistem pelayanan kesehatan yang melibatkan peserta, Fasilitas Kesehatan, dan BPJS Kesehatan dalam rangka pemeliharaan kesehatan bagi peserta BPJS Kesehatan yang menderita penyakit kronis yang dilaksanakan secara terintegratif dengan biaya pelayanan kesehatan yang efektif dan efisien untuk mencapai kualitas hidup yang optimal untuk mengetahui pengaruh senam prolanis terhadap penurunan tekanan darah pada lansia dengan hipertensi di Puskesmas Gunting Saga Kec. Kualuh Selatan Kab Labuhan Batu Utara 2019. Penelitian ini merupakan penelitian kuantitatif dengan metode quasi eksperimen, desain satu kelompok tanpa kelompok kontrol dengan menggunakan pre tes dan post tes design . Dilakukan terlebih dahulu penelitian atau pengukuran pada kelompok tersebut. Selanjutnya dilakukan uji coba kelompok tersebut dinilai kembali. Hasil penelitian didapatkan sebelum dilakukan intervensi senam prolanis dengan hasil rata -rata tekanan darah sistoloik 140-190 $\mathrm{mm} / \mathrm{Hg}$ dan diastolik $100-90 \mathrm{~mm} / \mathrm{Hg}$ dengan nilai 152.65 . Setelah dilakukan intervensi senam prolanis dengan hasil rata-rata tekanan darah sistolik $120-170 \mathrm{~mm} / \mathrm{Hg}$ dan diastolik $60-80$ $\mathrm{mm} / \mathrm{Hg}$, dengan nilai mean 137.21. Pengaruh program pengolahan penyakit kronis terhadap penurunan tekanan darah pada lansia hipertensi di Puskesmas Gunting Saga Kec. Kualuh Selatan Kab Labuhan Batu Utara diperoleh $p$ value 0.000 ( $\alpha$ 0.05), sehingga hasil penelitian hipotesa alternatif diterima. Disarankan bahwa hasil penelitian ini dapat menjadi dasar untuk pengembangan ilmu keperawatan geriatrik mengenai pengaruh pengaruh program pengolahan penyakit kronis terhadap penurunan tekanan darah pada lansia hipertensi di Puskesmas Gunting Saga Labuhan Batu Utara.
\end{abstract}

Kata kunci: PROLANIS, Tekanan darah, Hipertensi 


\begin{abstract}
PROLANIS is a proactive approach and health care system that involves participants, Health Facilities, and BPJS Health in the context of health care for BPJS Health participants who suffer from chronic diseases which is carried out in an integrated manner with cost effective and efficient health services to achieve optimal quality of life.Blood pressure is not constant but is influenced by many factors continuously throughout the day. Blood pressure can change from one heart beat to another even when it's at its best. High blood pressure or better known as hypertension is a condition where a person's blood pressure is above the normal or optimal limit, namely for systolic $120 \mathrm{mmHg}$ and for diastolic $80 \mathrm{mmHg}$. Patients who do not know they have hypertension before checking their blood pressure are categorized as the silent disease. The purpose of this study is that PROLANIS is a proactive approach and health care system that involves participants, Health Facilities, and BPJS Health in the context of health care for BPJS Health participants who suffer from chronic diseases which is carried out in an integrated manner with cost effective and efficient health services to achieve Optimal quality of life to determine the effect of prolanis exercise on reducing blood pressure in the elderly with hypertension at the Gunting Saga Health Center, Kec. South Kualuh, North Labuhan Batu Regency 2019. This research is a quantitative study with a quasi-experimental method, a one-group design without a control group using a pretest and post-test design. First, research or measurement is carried out in the group. The group was then reassessed.The results showed that blood pressure before the prolanis exercise intervention with an average result of $140-190 \mathrm{~mm} / \mathrm{Hg}$ systolic and $100-90 \mathrm{~mm} / \mathrm{Hg}$ diastolic with a value of 152.65. Blood pressure after prolanis exercise intervention with an average result of systolic $120-170 \mathrm{~mm} / \mathrm{Hg}$ and diastolic $60-80 \mathrm{~mm} / \mathrm{Hg}$, with a mean value of 137.21. The effect of the chronic disease treatment program on reducing blood pressure in the elderly with hypertension at the Gunting Saga Health Center, Kec. Kualuh Selatan Kab Labuhan Batu Utara obtained p value 0.000 ( $\alpha$ 0.05), so the results of the alternative hypothesis research are accepted.It is suggested that the results of this study can be the basis for the development of geriatric nursing knowledge regarding the effect of chronic disease treatment programs on reducing blood pressure in the elderly with hypertension at the Gunting Saga Health Center, North Labuhan Batu Regency.
\end{abstract}

Keywords: PROLANIS, blood pressure, hypertension

\title{
Pendahuluan
}

PROLANIS merupakan suatu pendekatan proaktif dan sistem pelayanan kesehatan yang melibatkan peserta, Fasilitas Kesehatan, dan BPJS Kesehatan dalam rangka pemeliharaan kesehatan bagi peserta BPJS Kesehatan yang menderita penyakit kronis yang dilaksanakan secara terintegratif dengan biaya pelayanan kesehatan yang efektif dan efisien untuk mencapai kualitas hidup yang optimal (BPJS Kesehatan, 2014).

Perry \& Potter, (2010) menjelaskan bahwa tekanan darah adalah kekuatan lateral pada dinding arteri oleh darah yang didorong dengan tekanan dari jantung. Tekanan darah merupakan tekanan yang ditimbulkan pada dinding arteri.Tekanan puncak terjadi saat ventrikel berkontraksi dan disebut tekanan sistolik.Tekanan diastolik adalah tekanan terendah yang terjadi saatjantung beristirahat. Smeltzer \& Bare, (2012) mengatakan bahwa tekanan darah dapat digambarkan sebagai rasio tekanan 
sistolik terhadap tekanan diastolik, dengan nilai berkisar dari 100/60 sampai 140/90 untuk dewasa normal dan biasanya rata-rata 120/80 untuk tekanan darah normal.

Baradero, (2008) mengemukakan bahwa penyakit darah tinggi atau yang lebih dikenal dengan sebutan hipertensi adalah suatu keadaan dimana tekanan darah seseorang berada diatas batas normal atau optimal yaitu untuk sistolik $120 \mathrm{mmHg}$ dan untuk diastolic $80 \mathrm{mmHg}$. Penderita yang tidak mengetahui dirinya mengidap hipertensi sebelum memeriksakan tekanan darahnya dikategorikan sebagai the silent disease. (Baradero, 2008).

Nugroho, (2008) mengatakan bahwa suatu proses menghilangnya secara perlahan-lahan kemampun jaringan untuk memperbaiki dan mempertahankan fungsi normalnya sehingga tidak dapat bertahan terhadap infeksi dan memperbaiki kerusakan yang di derita disebut menua. Nugroho, (2008) juga menjelaskan bahwa proses menua merupakan proses yang berlangsung sepanjang hidup, yang dimulai sejak permulaan kehidupan, sehingga merupakan proses alamiah yang berarti seseorang telah melalui tiga tahap kehidupan yaitu anak,dewasa, dan tua.

Pengaruh latihan fisik sangat terlihat bagi penyandang hipertensi dalam meningkatkan imunitas tubuh setelah latihan teratur, dapat mengatur kadar glukosa darah, meningkatkan sensitivitas reseptor insulin, menormalkan tekanan darah mencegah kegemukan, serta meningkatkan kemampuan kerja.Senam aerobik dapat membantu memperbaiki profil lemak darah, menurunkan kolesterol total, Low Density Lipoprotein (LDL), trigliserida dan menaikkan High Density Lipoprotein (HDL) serta memperbaiki sistem hemostatis dan tekanan darah.10,1.

Senam Prolanis (Program Pengelolahan Penyakit Kronis) merupakan salah satu program pemerintah yaitu bentuk latihan jasmani aerobik. Senam ini dijalankan oleh Badan Penyelengaraan Jaminan Sosial (BPJS) juga termasuk program pemerintah. Prolanis adalah suatu pendekatan proaktif dan sistem pelayanan kesehatan yang melibatkan peserta, Fasilitas Kesehatan, dan BPJS Kesehatan dalam rangka pemeliharaan kesehatan bagi peserta BPJS Kesehatan yang menderita penyakit kronis yang dilaksanakan secara terintegratif dengan biaya pelayanan kesehatan yang efektif dan efisien untuk mencapai kualitas hidup yang optimal.

Penelitian mengenai pengaruh senam prolanis terhadap penyandang hipertensi yang dilakukan oleh Lumempouw, Wungouw, \& Polli pada tahun 2016 menggunakan desain penelitian Quasy Eksperimental dengan rancangan "one group pre post test design" dalam waktu 4 minggu menunjukkan adanya perbedaan yang signifikan antara tekanan darah sistolik maupun diastolik baik awal dan akhir latihan. Pada latihan $2 \mathrm{kali} /$ minggu awal dan akhir tekanan darah sistolik $(\mathrm{p}=0,003)$ dan tekanan darah diastolik $(\mathrm{p}=0,002)$. Pada latihan $3 \mathrm{kali} /$ minggu awal dan akhir tekanan darah sistolik $(\mathrm{p}=0,000)$, dan tekanan darah diastolik $(\mathrm{p}=0,000)$.

Hasil studi pendahuluan pada tanggal 2 Oktober 2017 di Puskesmas Gunting Saga Kabupaten Labuhan Batu Utara didapatkan data jumlah penderita hipertensi pada laki-laki sebanyak 1.053 orang $(19,83 \%)$, perempuan sebanyak 2.210 orang (90,57\%), laki-laki dan perempuan 3.263 orang $(42,10 \%)$. Jumlah peserta program prolanis sebanyak 204 orang. Sedangkan yang aktif ikut senam prolanis secara rutin tiap minggu sebanyak 50 orang, dengan penderita hipertensi sebanyak 34 orang. 


\section{Metode Penelitian}

Penelitian ini menggunakan metode penelitian quasi eksperimen, desain satu kelompok tanpa kelompok kontrol dengan menggunakan pre tes dan post tes design. Penelitian telah dilaksanakan di Puskesmas Gunting Saga Kec. Kualuh Selatan Kab Labuhan Batu Utara, Penelitian ini dimulai sejak bulan Januari - Februari 2020. Populasi pada penelitian ini adalah lansia yang menderita hipertensi di Puskesmas Gunting Saga Labuhan Batu Utara yang berjumlah 189 orang. Peneliti pada penelitian ini menggunakan tehnik Purposive sampling Analisis data ini digunakan untuk menganalisis data kuantitatif yang merupakan hasil perlakuan (treatment).

\section{Hasil dan Pembahasan}

Tabel 4.1. Distribusi Hasil Karakteristik Responden

\begin{tabular}{|c|c|c|c|}
\hline No. & Karakteristik Responden & Frekuensi (f) & Persentase (\%) \\
\hline \multirow[t]{4}{*}{1.} & Umur & & \\
\hline & $<60$ tahun & 6 & 17.6 \\
\hline & $>60$ tahun & 28 & 82.4 \\
\hline & Total & 34 & 100.0 \\
\hline \multirow[t]{3}{*}{2.} & Pendidikan & & \\
\hline & SD-SMP & 17 & 50.0 \\
\hline & SMA-PT & 17 & 50.0 \\
\hline & Total & 34 & 100.0 \\
\hline \multirow[t]{4}{*}{4} & jenis kelamin & & \\
\hline & laki -laki & 20 & 58.8 \\
\hline & perempuan & 14 & 41.2 \\
\hline & Total & 34 & 100.0 \\
\hline
\end{tabular}

Sumber : Data Primer 2020

Berdasarkan hasil penelitian didapatkan mengenai umur responden bahwa responden yang berumur $>56$ tahun sebanyak 28 orang $(82.4 \%)$. Berdasarkan pendidikan bahwa responden yang ber pendidikan tinggi berjumlah 17 orang $(58,8 . \%)$. Untuk jenis kelamin bahwa responden yang ber jenis kelamin tinggi laki-laki sebanyak 20 orang (50.\%).

Tabel 4.2. Latihan 2 kali/minggu (Tekanan Darah Sistolik dan Diastolik Sebelum dan Sesudah Latihan)

\begin{tabular}{|c|c|c|c|}
\hline \multicolumn{2}{|c|}{$\begin{array}{l}\text { Tekanan Darah } \\
\text { Sistolik } \mathrm{mm} / \mathrm{Hg}\end{array}$} & \multicolumn{2}{|c|}{$\begin{array}{c}\text { Tekanan Darah } \\
\text { Diastolik mm/Hg }\end{array}$} \\
\hline Sebelum & Sesudah & Sebelum & Sesudah \\
\hline $\begin{array}{l}140-190 \\
\mathrm{~mm} / \mathrm{Hg}\end{array}$ & $120-170 \mathrm{~mm} / \mathrm{Hg}$ & $100-90 \mathrm{~mm} / \mathrm{Hg}$ & $60-80 \mathrm{~mm} / \mathrm{Hg}$ \\
\hline
\end{tabular}

Berdasarkan Tabel 4.2 memperlihatkan bahwa latihan 2 kali/minggu dengan tekanan darah sistolik sebelum latihan yaitu rata- rata $140-190 \mathrm{~mm} / \mathrm{Hg}$ terjadi penurunan sesudah latihan menjadi $120-170 \mathrm{~mm} / \mathrm{Hg}$; dan tekanan darah diastolik sebelum latihan 
yaitu rata-rata $100-90 \mathrm{~mm} / \mathrm{Hg}$ mengalami juga penurunan sesudah latihan menjadi ratarata $60-80 \mathrm{~mm} / \mathrm{Hg}$.

Tabel 4.3. Pengaruh Senam Program Pengolahan Penyakit Kronis (Prolanis)

Terhadap Penurunan Tekanan Darah Pada Lansia Hipertensi

\begin{tabular}{llcc}
\hline $\begin{array}{c}\text { Pengaruh } \\
\text { Penkes }\end{array}$ & Mean & Standar Deviasi & $p$-value \\
\hline Sebelum & 152.65 & 15.237 & .000 \\
\hline Sesudah & 137.21 & 14.312 & \\
\hline
\end{tabular}

Hasil uji Wilcoxon, diperoleh nilai kemaknaan 0.000 ( $\mathrm{p}<0.05)$, dengan demikian disimpulkan terdapat perbedaan tekanan darah pada lansia penderita hipertensi yang signifikan antara sebelum dan setelah dilakukan senam prolanis. Dan hipotesa alternatif (Ha) diterima dan Ho ditolak.

\section{Latihan 2 kali/minggu (Tekanan Darah Sistolik dan Diastolik Sebelum dan Sesudah Latihan )}

Penelitian dilakukan terhadap 34 orang penderita hipertensi di Di Puskesmas Gunting Saga Kec. Kualuh Selatan Kab Labuhan Batu Utara. yang mengikuti senam Prolanis dilakukan latihan $2 \mathrm{kali} /$ minggu setiap hari selasa dan jumat. Perlakuan berupa senam Prolanis selama 60 menit. Responden didominasi oleh jenis kelamin laki-laki (58.8\%) . Umur responden berkisar > 60 tahun tahun (82.4\%). latihan $2 \mathrm{kali} / \mathrm{minggu}$ dengan tekanan darah sistolik sebelum latihan yaitu rata- rata $140-190 \mathrm{~mm} / \mathrm{Hg}$ terjadi penurunan sesudah latihan menjadi $120-170 \mathrm{~mm} / \mathrm{Hg}$; dan tekanan darah diastolik sebelum latihan yaitu rata-rata $100-90 \mathrm{~mm} / \mathrm{Hg}$ mengalami juga penurunan sesudah latihan menjadi rata-rata $60-80 \mathrm{~mm} / \mathrm{Hg}$. Frekuensi latihannya 2 kali dalam seminggu dengan lama latihan 30-60 menit sekali latihan. Latihan olahraga dapat menyebabkan dilatasi pembuluh-pembuluh darah sehingga tekanan darah menurun. Latihan 2 kali seminggu akan mengalami peningkatan daya tahan kardiorespirasi dan latihan olahraga secara teratur bisa menurunkan resiko penyakit jantung.

Seiring dengan penelitian dari Rismayanthi (2013) mengatakan bahwa olahraga prolanis terutama bermanfaat untuk meningkatkan dan mempertahankan kesehatan dan daya tahan jantung, paru, peredaran darah, otot-otot, dan sendi-sendi. Senam prolanis akan memberi pengaruh besar terhadap tubuh, khususnya terhadap daya tahan paru dan jantung.

\section{Pengaruh Senam Program Pengolahan Penyakit Kronis (Prolanis) Terhadap Penurunan Tekanan Darah Pada Lansia Hipertensi}

Latihan fisik sangat berpengaruh bagi penderita hipertensi untuk meningkatkan imunitas dalam tubuh setelah latihan teratur, meregulasi kadar glukosa darah, meningkatkan sensitivitas reseptor insulin, mencegah kegemukan, menormalkan tekanan darah serta meningkatkan kemampuan kerja. Sedangkan senam aerobik dapat memperbaiki profil lemak darah, menurunkan kolesterol total, membantu Low Density Lipoprotein (LDL), trigliserida dan menaikkan High Density Lipoprotein (HDL) serta memperbaiki sistem hemostatis dan tekanan darah. 
Hal ini sesuai dengan teori Hasanudin et al. (2018) yang mengatakan aktivitas fisik yang kurang menyebabkan tekanan darah meningkat. Dengan berolahraga atau melakukan aktivitas fisik secara rutin sehingga dapat menurunkan atau menstabilkan tekanan darah. Hal ini diperkuat oleh Börjesson et al. (2015) yang mengatakan setelah selesai aktivitas senam aerobic, kemudian tekanan darah akan berkurang di bawah tekanan darah saat istirahat yang disebut dengan hipotensi pasca-latihan ini terjadi pada pasien hipertensi yang mengalami peningkatan tekanan darah berlebihan. Penurunan tekanan darah bisa berkurang 10-20 $\mathrm{mmHg}$ dan biasanya bertahan setelah latihan.

Sejalan juga dengan penelitian yang dilakukan oleh Aji et al. (2015) bahwa senam lansia mempengaruhi penurunan tekanan darah sistolik maupun diastolik, hal ini terbukti dengan didapatkan hasil analisis pada tekanan darah sistolik sebelum dan sesudah perlakuan yaitu nilai Pvalue $=0,024$. Sedangkan hasil analisis pada tekanan darah diastolic sebelum dan sesudah perlakuan didapatkan nilai Pvalue $=0,010$ yang artinya terdapat pengaruh senam lansia pada tekanan darah sistolik maupun diastolic responden. Tekanan darah dapat menurunan pada responden yang melaksanakan senam Prolanis seperti yang dijelaskan diatas dalam penelitianya dilakukan dengan tidak mengendalikan variabel perancu yaitu obat dan diet hipertensi pada responden setiap minggunya.

\section{Kesimpulan}

Kesimpulan yang dapat diambil dari hasil analisis data tentang "pengaruh program pengolahan penyakit kronis terhadap penurunan tekanan darah pada lansia hipertensi di Puskesmas Gunting Saga Kec. Kualuh Selatan Kab Labuhan Batu Utara 2020" yaitu sebagai berikut: Tekanan darah sebelum dilakukan intervensi senam prolanis dengan hasil rata -rata sistoloik $140-190 \mathrm{~mm} / \mathrm{Hg}$ dan diastolik $100-90 \mathrm{~mm} / \mathrm{Hg}$ dengan nilai 152.65. Tekanan darah setelah dilakukan intervensi senam prolanis dengan hasil rata-rata sistolik $120-170 \mathrm{~mm} / \mathrm{Hg}$ dan diastolik $60-80 \mathrm{~mm} / \mathrm{Hg}$, dengan nilai mean 137.21. Pengaruh program pengolahan pesnyakit kronis terhadap penurunan tekanan darah pada lansia hipertensi di Puskesmas Gunting Saga Kec. Kualuh Selatan Kab Labuhan Batu Utara diperoleh $p$ value $0.000(\alpha$ 0.05), sehingga hasil penelitian hipotesa alternatif diterima.

\section{Referensi}

Aji, W. P. B., Isnaeni, Y., Sugiyanto. (2015). Pengaruh Senam Lansia Terhadap Tekanan Darah Pada Lansia Penderita Hipertensi Di Posyandu Lansia Dusun Banaran 8 Playen Gunungkidul. Jurnal STIKES Aisyiah Yogyakarta

Asikin, M., M. Nuralamsyah., Susaldi. (2016). Keperawatan Medikal Bedah: Sistem Kardiovaskule. Jakarta: Erlangga

BPJS. (2015). Panduan praktis PROLANIS (Program pengelolaan penyakit kronis). In BPJS Kesehatan. Jakarta: badan penyelenggara jaminan sosial kesehatan.

Dalimartha., Setiawan.( 2008). Care Your Self Hipertensi. Penebar Plus : Jakarta 
JINTAN : Jurnal Ilmu Keperawatan

ISSN 2774-468X (Media Online)

Vol 1, No 2, Bulan Juli 2021

Hal 57-64

Hidayat, A.A. (2011). Metode Penelitian Kebidanan dan Teknik Analisis Data. Jakarta: Salemba Medika.

Lestari, N. L. inten. (2016). Analisis implementasi Program pengelolaan penyakit Kronis pada Puskesmas di kabupaten Tabanan tahun 2016. Denpasar.

Lumempouw, D. O., Wungouw, H. I. S., \& Polii, H. (2016). Pengaruh senam Prolanis terhadap penyandang hipertensi. eBM PAAI, 4, 1-6.

Maryam, S. (2008). Menengenal Usia Lanjut dan Perawatannya. Jakarta: Salemba Medika.

Muttaqin, A. (2009). Asuhan Keperawatan Klien dengan Gangguan Sistem Kardiovaskular. Jakarta:Salemba Medika

Notoatmodjo, S. (2010) . Metodologi Penelitian Kesehatan. Jakarta: Rineka Cipta.

Nursalam. (2013). Metodologi Penelitian Ilmu Keperawatan: Pendekatan Praktis : Jakarta : Salemba Medika

Rosdiana, A. I., Raharjo, B. B., \& Indarjo, S. (2017). Implementasi Program Pengelolaan Penyakit Kronis (Prolanis). Higeia Journal Of Public Health Research and Development, 1(3), 140-150. Retrieved from http://journal.unnes.ac.id/sju/index.php/higeia

Saferi, A dan Mariza, Y. (2013). KMB 2 Keperawatan Medikal Bedah (Keperawatan Dewasa Teori dan Contoh Askep). Yogyakarta:Nuha medika

Sustrani, L., S. Alam., dan I. Hadibroto. (2015). Hipertensi. Jakarta: PT Gramedia Pustaka Utama.

Udjianti, W.J. (2010). Keperawatan Kardiovaskuler. Jakarta: Salemba Medika. 